\title{
Perioperative Renal \\ Pharmacological Protection During Cardiovascular Surgery
}

\author{
Alessandro Belletti, Margherita Licheri, \\ and Tiziana Bove
}

\subsection{Introduction}

Acute kidney injury (AKI), previously known also as acute renal failure, is a syndrome characterized by a rapid decline in kidney function (within hours to days) [1], with associated alterations in metabolic, electrolyte, and fluid homeostasis. It has been estimated that more than $20 \%$ of hospitalized patients develop AKI [2-4], and AKI is associated with increased short- and long-term morbidity and mortality, including an increased risk of developing chronic kidney disease (CKD) $[5,6]$.

Accordingly, AKI is now considered a major health problem worldwide [7, 8], which acquires particular importance considering that several cases of hospital-acquired AKI are iatrogenic [9].

Unfortunately, cardiovascular surgery is considered a major risk factor for AKI development $[3,10,11]$. In this chapter, we will review current definition, epidemiology and available

\footnotetext{
A. Belletti

Department of Anesthesia and Intensive Care, IRCCS San Raffaele Scientific Institute, Milan, Italy

M. Licheri

Department of Medical Sciences and Public Health "M. Aresu", University of Cagliari, Cagliari, Italy

T. Bove $(\bowtie)$

Department of Medicine, University of Udine, Udine, Italy

e-mail: tiziana.bove@uniud.it
}

pharmacological strategies to prevent and treat AKI in aortic surgery.

\subsection{Acute Kidney Injury: Definition and Epidemiology}

Until the last decade, the definition of AKI was highly variable across different studies, yielding to a large heterogeneity in reported incidences and associated outcomes as well as lack of comparative data. In 2004, an international consensus conference developed a standard definition and staging system for AKI based on serum creatinine and urine output, called RIFLE (risk, injury, failure, loss, end-stage kidney disease) classification (Table 16.1) [12]. Later, RIFLE criteria were modified into the AKIN (Acute Kidney Injury Network) criteria [13], to account for the increase in mortality observed for even small increase in serum creatinine [14] (Table 16.1). Finally, RIFLE and AKIN criteria were merged in a single definition proposed by the 2012 Kidney Disease: Improving Global Outcome (KDIGO) clinical practice guidelines on AKI [10-15] (Table 16.1). A standard definition for AKI after endovascular aneurysm repair (EVAR), the Aneurysm Renal Injury Score (ARISe), has also been recently developed [16] (Table 16.2).

Incidence of AKI in aortic surgery is highly variable, depending on surgical technique (open versus endovascular), site (ascending aorta/aortic 


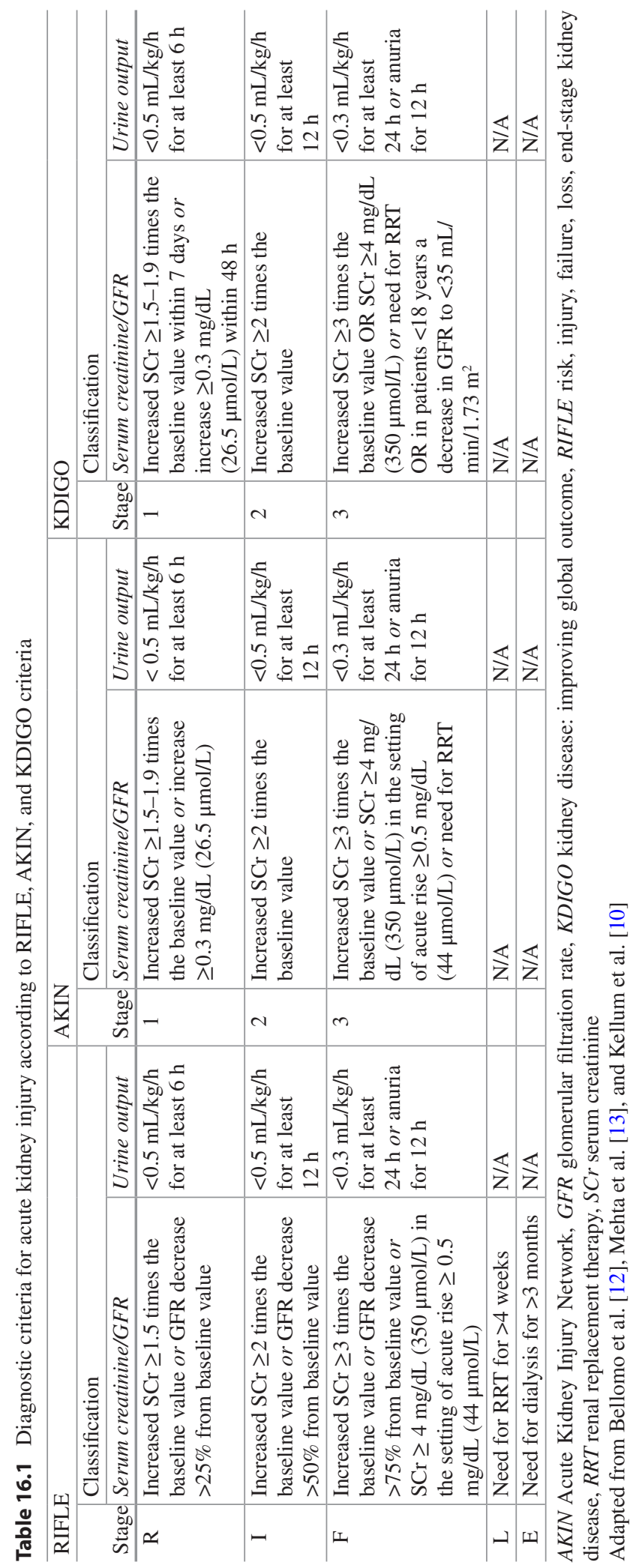


Table 16.2 Diagnostic criteria for acute kidney injury according to ARISe criteria

\begin{tabular}{|c|c|c|}
\hline \multirow[b]{2}{*}{ Stage } & \multicolumn{2}{|l|}{ Classification } \\
\hline & Creatinine/GFR & Urine output \\
\hline 1 & Increased $\mathrm{SCr}>0.3 \mathrm{mg} / \mathrm{dL}(26.5 \mu \mathrm{mol} / \mathrm{L})$ or $<50 \%$ of baseline within $48 \mathrm{~h}$ & $<0.5 \mathrm{~mL} / \mathrm{kg} / \mathrm{h}$ for $>6 \mathrm{~h}$ \\
\hline 2 & $50 \%$ to $99 \%$ rise in $\mathrm{SCr}$ from the preoperative value within 7 days & \\
\hline 3 & $>100 \%$ rise in serum creatinine from the preoperative value within 7 days & \\
\hline 4 & Need for RRT & \\
\hline 5 & Permanent RRT & \\
\hline
\end{tabular}

$R R T$ renal replacement therapy

Adapted from Twine et al. [16]

arch, descending thoracic aorta, suprarenal and infrarenal abdominal aorta), and urgency of the procedure (elective versus urgent). Procedures involved requiring suprarenal aortic cross-clamp and renal ischemia clearly carry the highest risk.

In the largest case series on open thoracoabdominal aortic aneurysm (TAAA) repair, Coselli et al. described outcome of 3309 patients. Of these, $12.3 \%$ had acute renal dysfunction (defined as doubling of serum creatinine or need for RRTroughly corresponding to KDIGO AKI stage $\geq 2$ ) and $7.6 \%$ required postoperative renal replacement therapy (RRT), with $5.6 \%$ still requiring dialysis at hospital discharge or at time of inhospital death [17]. Tshomba et al. performed a propensity-matched study on 84 open TAAA patients, reporting a $42.9 \%$ incidence of stage 1 AKI (according to AKIN criteria), with $4.7 \%$ patients requiring RRT and no patients requiring dialysis at discharge [18]. In their case series of 455 patients undergoing open TAAA repair, Wynn et al. reported a 17\% incidence of RIFLE$\mathrm{R}$ AKI and a $2.7 \%$ incidence of AKI requiring renal replacement therapy (RRT). Permanent dialysis was required in three $(0.66 \%)$ cases [19]. Considering surgery for acute aortic dissection, the incidence of AKI may be more than $50 \%$ [20-22], with need for RRT in more than $10 \%$ of patients [20,21]. Dariane and colleagues recently performed a systematic review of AKI incidence in open repair of intact abdominal aortic aneurysm (AAA) [23], including only studies using modern standardized criteria for AKI definition (RIFLE, AKIN, KDIGO, or ARISe). In cases of suprarenal aortic cross-clamp, incidence of AKI may be up to $36.8 \%$ and need for RRT up to $3.8 \%$. For infrarenal clamping, incidence of AKI was reported in about $25 \%$ of cases, with $0.3 \%$ of patients requiring RRT. In patients undergoing surgery for ruptured AAA (rAAA), AKI incidence rises up to 75\% of patients [24-26].

Patients undergoing endovascular aortic procedures are also at high risk for postoperative AKI. In thoracic endovascular aortic repair (TEVAR), modern case series using RIFLE criteria to define AKI reported incidences of $14-22 \%$, with RRT required in $0.6-7 \%$ of patients [2729]. A similar incidence was found in TEVAR for type B aortic dissection [30] Incidence of RIFLE-, AKIN-, KDIGO- or ARISe-defined AKI after EVAR is similar, with a 5-19\% reported incidence, with most of studies reporting a $0 \%$ rate of dialysis [31].

\subsection{Identification of Patients at Risk}

Risk stratification for postoperative AKI is of utmost importance in order to tailor perioperative management according to patient risk. Risk factors for AKI can be related to patients' baseline comorbidities [10, 32]. Importantly, duration of renal ischemia is a key determinant of postoperative AKI in abdominal aortic procedures.

To aid clinicians in stratifying risk objectively, risk scores for postoperative AKI have been developed [33-40]. Importantly, most of these risk scores have been developed to predict need for RRT after cardiac surgery, while specific scores for vascular surgery are currently lacking [41]. Among the different scores, a recent systematic review identified the Cleveland Clinic Score by Thakar et al. (Table 16.3) to have the 
Table 16.3 Cleveland clinic score for acute kidney injury requiring dialysis after cardiac surgery

\begin{tabular}{|c|c|c|}
\hline Risk factor & \multicolumn{2}{|l|}{ Score } \\
\hline Female sex & \multicolumn{2}{|l|}{1} \\
\hline Congestive heart failure & \multicolumn{2}{|l|}{1} \\
\hline $\mathrm{LVEF}<35 \%$ & \multicolumn{2}{|l|}{1} \\
\hline $\begin{array}{l}\text { Preoperative need for } \\
\text { IABP }\end{array}$ & \multicolumn{2}{|l|}{2} \\
\hline COPD & \multicolumn{2}{|l|}{1} \\
\hline $\begin{array}{l}\text { Insulin-dependent } \\
\text { diabetes }\end{array}$ & \multicolumn{2}{|l|}{1} \\
\hline Previous cardiac surgery & \multicolumn{2}{|l|}{1} \\
\hline Emergency surgery & \multicolumn{2}{|l|}{2} \\
\hline Valve surgery only & \multicolumn{2}{|l|}{1} \\
\hline $\mathrm{CABG}+$ valve surgery & \multicolumn{2}{|l|}{2} \\
\hline Other cardiac surgery & \multicolumn{2}{|l|}{2} \\
\hline $\begin{array}{l}\text { Preoperative } \mathrm{SCr} \\
1.2-2.1 \mathrm{mg} / \mathrm{dL}\end{array}$ & \multicolumn{2}{|l|}{2} \\
\hline $\begin{array}{l}\text { Preoperative } \mathrm{SCr} \\
>2.1 \mathrm{mg} / \mathrm{dL}\end{array}$ & \multicolumn{2}{|l|}{5} \\
\hline Risk categories & $\begin{array}{l}\text { Total } \\
\text { score }\end{array}$ & $\begin{array}{l}\text { RRT } \\
\text { incidence }(\%)\end{array}$ \\
\hline 1 & $0-2$ & 0.4 \\
\hline 2 & $3-5$ & 1.8 \\
\hline 3 & $6-8$ & 9.5 \\
\hline 4 & $9-13^{a}$ & 21.3 \\
\hline
\end{tabular}

$C A B G$ coronary artery bypass graft, $C O P D$ chronic obstructive pulmonary disease, $I A B P$ intra-aortic balloon pump, $L V E F$ left ventricular ejection fraction, $R R T$ renal replacement therapy

Adapted from Thakar et al. [33]

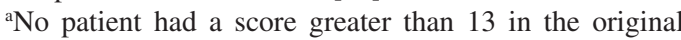
dataset

highest predictive value [42]. Whether this score can also be applied to patients undergoing aortic vascular surgery remains to be determined.

\subsubsection{Contrast-Induced Acute Kidney Injury}

Administration of intravenous contrast media is common during vascular surgical procedures. It is almost always required during endovascular procedures and is sometimes also used following open surgery to confirm vessel patency (e.g., in the oliguric patient following procedures on renal arteries). As contrast media administration is one of the most common causes of iatrogenic AKI, prevention of CI-AKI remains a key issue in renal protection. Therefore, preoperative risk stratification of patients should also consider the risk of CI-AKI.

Unfortunately, up to now, most studies investigating incidence and risk factors for CI-AKI focus on percutaneous coronary interventions [43]. This setting is clearly different from vascular surgery, as patients undergoing vascular surgery may have a greater number of concomitant kidney insults, such as renal ischemia related to aortic or renal arteries cross-clamp, severe blood loss, and hemodynamic instability. The risk of contrast-induced acute kidney injury (CI-AKI) is considered to become clinically important when the baseline serum creatinine concentration is $\geq 1.3 \mathrm{mg} / \mathrm{dL}$ in men and $\geq 1.0 \mathrm{mg} / \mathrm{dL}$ in women, equivalent to an estimated glomerular filtration rate (eGFR) $<60 \mathrm{~mL} / \mathrm{min}$ [44]. As a general rule, patients may be simply stratified in low, intermediate, and high risk depending on GFR and clinical history [45]. Patients with no history of diabetes, heart failure, or monoclonal gammopathy and eGFR $>60 \mathrm{~mL} / \mathrm{min} / 1.73 \mathrm{~m}^{2}$ should be considered at low risk. Patients with eGFR $30-60 \mathrm{~mL} / \mathrm{min} / 1.73 \mathrm{~m}^{2}$ or eGFR $45-60 \mathrm{~mL} /$ $\mathrm{min} / 1.73 \mathrm{~m}^{2}$ together with heart failure or diabetes carry an intermediate risk. Finally, patients with monoclonal gammopathy and eGFR $\leq 30 \mathrm{~mL} / \mathrm{min} / 1.73 \mathrm{~m}^{2}$ regardless of comorbidities and patients with eGFR $\leq 45 \mathrm{~mL} / \mathrm{min} / 1.73 \mathrm{~m}^{2}$ together with diabetes or heart failure are all considered at high risk [41].

Mehran et al., after analyzing 8357 patients undergoing percutaneous coronary intervention (PCI), proposed a clinical risk score allowing for immediate identification of the variables accounted for before the procedure and appropriate (and timely) risk allocation. It is based on eight readily available variables: (1) patientrelated characteristics (age $>75$ years, diabetes mellitus, chronic congestive heart failure, or admission with acute pulmonary edema, hypotension, anemia, and chronic kidney disease) and (2) procedure-related characteristics (i.e., the use of elective IABP or increasing volumes of contrast media). Patients scoring positive for at least three risk factors will have a $26 \%$ probability 
Table 16.4 Clinical risk score for contrast-induced acute kidney injury

\begin{tabular}{|c|c|c|c|}
\hline Risk factor & \multicolumn{3}{|l|}{ Score } \\
\hline $\begin{array}{l}\text { Hypotension (SBP }<80 \mathrm{mmHg} \text { for at least } 1 \mathrm{~h} \\
\text { requiring inotropic support or IABP in the } 24 \mathrm{~h} \\
\text { before procedure) }\end{array}$ & \multicolumn{3}{|l|}{5} \\
\hline IABP use & \multicolumn{3}{|l|}{5} \\
\hline $\begin{array}{l}\text { Congestive heart failure (NYHA class III/IV or } \\
\text { history of pulmonary edema) }\end{array}$ & \multicolumn{3}{|l|}{5} \\
\hline Age $>75$ years & \multicolumn{3}{|l|}{4} \\
\hline Anemia (Hct <39\% for men and 36\% for women) & \multicolumn{3}{|l|}{3} \\
\hline Diabetes mellitus & \multicolumn{3}{|l|}{3} \\
\hline Contrast volume & \multicolumn{3}{|l|}{$1 / 100 \mathrm{~mL}$} \\
\hline \multicolumn{4}{|l|}{ Serum creatinine or GFR (use only one parameter) } \\
\hline - Serum creatinine $>1.5 \mathrm{mg} / \mathrm{dL} O R$ & \multicolumn{3}{|l|}{4} \\
\hline \multicolumn{4}{|l|}{$\cdot$ GFR } \\
\hline$-40-60 \mathrm{~mL} / \mathrm{min} / 1.73 \mathrm{~m}^{2}$ & \multicolumn{3}{|l|}{2} \\
\hline$-20-39 \mathrm{~mL} / \mathrm{min} / 1.73 \mathrm{~m}^{2}$ & \multicolumn{3}{|l|}{4} \\
\hline$-<20 \mathrm{~mL} / \mathrm{min} / 1.73 \mathrm{~m}^{2}$ & \multicolumn{3}{|l|}{6} \\
\hline Risk categories & Total score & AKI incidence (\%) & RRT incidence (\%) \\
\hline Low & $\leq 5$ & 7.5 & 0.04 \\
\hline Moderate & $6-10$ & 14 & 0.12 \\
\hline High & $11-15$ & 26.1 & 1.09 \\
\hline Very high & $\geq 16$ & 57.3 & 12.6 \\
\hline
\end{tabular}

$A K I$ acute kidney injury, GFR glomerular filtration rate, Hct hematocrit, IABP intra-aortic balloon pump, NYHA New York Heart Association, RRT renal replacement therapy

Adapted from Mehran et al. [46]

of developing CI-AKI and a $1 \%$ probability of needing dialysis following PCI [46] (Table 16.4).

\subsection{Preventive Strategies}

Considering the high-risk and prognostic impact of perioperative AKI in cardiovascular surgery, the development of strategies aimed at preventing AKI in this setting has always been a major topic in research. Although a large number of studies investigating several strategies have been conducted, only few demonstrated a clear positive effect, while most led to neutral or controversial results [15, 32, 41, 47, 48]. As outlined by recent guidelines, the most important preventive measures are the maintenance of adequate renal perfusion and avoidance of nephrotoxic drugs $[15,32,47]$. Importantly, a recent expert opinion paper from the European Society of Intensive Care Medicine was able to formulate strong recommendations with high level of evidence only against some interventions and none in favor [47].

\subsubsection{Primum Non Nocere: Avoiding Nephrotoxins}

Unfortunately, AKI is considered to be iatrogenic in several cases [41]. Several drugs can contribute to AKI development, including renin-angiotensin-aldosterone system (RAAS) blockers, nonsteroidal anti-inflammatory drugs (NSAIDs), aminoglycosides, amphotericin $\mathrm{B}$, and contrast media [49]. Some categories of patients have a particularly increased risk of drug-induced AKI, such as older, volume-depleted patients or hemodynamically unstable patients [49]. The first step of AKI prevention is therefore to avoid drugs which can induce or exacerbate AKI as much as possible.

Several patients undergoing cardiovascular surgery are treated with RAAS, and optimal management of these agents in the perioperative period remains controversial. Current guidelines recommend to discontinue angiotensin-converting enzyme inhibitors (ACE-Is) and angiotensin receptors blockers (ARBs) before cardiac 
surgery, albeit with a low level of evidence [50]. In patients with difficult-to-control hypertension, switching long-acting to short-acting ACE-Is/ ARBs should be considered.

Similarly, it is reasonable to avoid NSAIDs in the perioperative period in high-risk patients, using alternative drugs such as opioids or paracetamol (acetaminophen) to treat pain $[50,51]$.

It is intuitive that antimicrobial agents alternative to aminoglycosides and amphotericin $\mathrm{B}$ should be used when feasible [15]. When this is not possible, international guidelines recommend to administer a single daily dose of aminoglycosides rather than multiple-dose daily treatment and to monitor drug levels to avoid excessive dosing [15]. If amphotericin B is deemed necessary, lipid formulation should be used rather than conventional formulation [15].

Finally, it should be remembered that CIAKI is among the most common causes of iatrogenic AKI. Accordingly, benefits and risk of contrast media administration should be adequately weighted before planning a diagnostic or therapeutic procedure requiring intravenous contrast media administration, especially in high-risk patients (e.g., patients with a Mehran score greater than 16). If a diagnostic procedure requiring IV contrast media is deemed necessary, it might be reasonable to delay subsequent elective high-risk surgery or other procedures requiring contrast media (Table 16.5) for a few days, especially if concomitant nephrotoxic agents are being used. However, some recent studies suggested that the risk of CI-AKI may actually be overestimated [52]. Accordingly, while it is reasonable to search for alternative diagnostic tools or delay procedures in elective cases, urgent and life-saving procedures should not be deferred or denied only because of CIAKI risk.

Table 16.5 Suggested strategy for contrast-induced acute kidney injury prevention

\begin{tabular}{|c|c|c|c|}
\hline & Low risk & Intermediate risk & High risk \\
\hline Stratification & $\begin{array}{l}\text { eGFR }>60 \mathrm{~mL} / \mathrm{min} / 1.73 \mathrm{~m}^{2} \\
\text { and no monoclonal } \\
\text { gammopathy }\end{array}$ & $\begin{array}{l}\text { - eGFR } 30-60 \mathrm{~mL} / \mathrm{min} / \\
1.73 \mathrm{~m}^{2} \text { and no heart } \\
\text { failure } \\
\text { - eGFR } 45-60 \mathrm{~mL} / \mathrm{min} / \\
\\
1.73 \mathrm{~m}^{2} \text { and diabetes or } \\
\text { heart failure }\end{array}$ & $\begin{array}{l}\text { - eGFR }<30 \mathrm{~mL} / \mathrm{min} / 1.73 \mathrm{~m}^{2} \text { and } \\
\text { no heart failure } \\
\text { - eGFR }<45 \mathrm{~mL} / \mathrm{min} / 1.73 \mathrm{~m}^{2} \text { and } \\
\text { diabetes or heart failure } \\
\text { - Monoclonal gammopathy }\end{array}$ \\
\hline $\begin{array}{l}\text { Volume } \\
\text { expansion }\end{array}$ & $\begin{array}{l}\text { Liberal fluid intake } \\
-1 \mathrm{~L} \text { over } 12 \mathrm{~h} \text { before } \\
\text { contrast administration } \\
\text { and } 1 \mathrm{~L} \text { over } 12 \mathrm{~h} \text { after } \\
\text { contrast administration }\end{array}$ & $\begin{array}{l}\text { Oral volume expansion } \\
\text { schedule } \\
-1 \mathrm{~g} \mathrm{NaCI}+150 \mathrm{~mL} \text { of } \mathrm{H}_{2} \mathrm{O} \\
\text { every hour from } 2 \mathrm{~h} \text { before } \\
\text { until } 6 \mathrm{~h} \text { after contrast } \\
\text { administration }\end{array}$ & $\begin{array}{l}\text { IV volume expansion schedule with } \\
\text { one of these regimens } \\
-1 \mathrm{~L} \mathrm{NaCI} 0.9 \% \text { over } 12 \mathrm{~h} \text { before } \\
\text { and after contrast administration } \\
-1 \mathrm{~L} \text { glucose } 5 \%+150 \mathrm{mmol} / \mathrm{L} \\
\text { bicarbonate } 8.4 \%, 3 \mathrm{~mL} / \mathrm{kg} / \mathrm{h} \\
\text { over } 1 \mathrm{~h} \text { before and } 1 \mathrm{~mL} / \mathrm{kg} / \mathrm{h} \\
\text { during } 6 \mathrm{~h} \text { after contrast } \\
\text { administration }\end{array}$ \\
\hline $\begin{array}{l}\text { General } \\
\text { management }\end{array}$ & $\begin{array}{l}\text { - Avoid repetitive contrast } \\
\text { administration (<7 days } \\
\text { after previous contrast } \\
\text { administration) } \\
\text { - Reschedule if possible in } \\
\text { case of recent (i.e., within } \\
72 \mathrm{~h} \text { ) use of nonsteroidal } \\
\text { anti-inflammatory drugs }\end{array}$ & $\begin{array}{l}\text { - Avoid repetitive contrast } \\
\text { administration }(<7 \text { days } \\
\text { after previous contrast } \\
\text { administration) } \\
\text { - Reschedule if possible in } \\
\text { case of recent (i.e., within } \\
72 \mathrm{~h} \text { ) use of nonsteroidal } \\
\text { anti-inflammatory drugs }\end{array}$ & $\begin{array}{l}\text { - Avoid repetitive contrast } \\
\text { administration (<7 days after } \\
\text { previous contrast administration) } \\
\text { - Reschedule if possible in case of } \\
\text { recent (i.e., within } 72 \mathrm{~h} \text { ) use of } \\
\text { nonsteroidal anti-inflammatory } \\
\text { drugs } \\
\text { - Stop metformin } 48 \mathrm{~h} \text { before the } \\
\text { procedure and restart } 72 \mathrm{~h} \text { after } \\
\text { the procedure }\end{array}$ \\
\hline
\end{tabular}

$e G F R$ estimated glomerular filtration rate

Adapted from Vanmassenhove et al. [41] 


\subsubsection{General Hemodynamic Management: MAP and Fluids}

Maintenance of an adequate level of mean arterial pressure (MAP) is a mainstay of AKI prevention. However, the optimal target MAP remains to be determined, particularly for chronically hypertensive patients (who consists a large proportion of patients undergoing vascular surgery). In an observational trial including 33,330 noncardiac surgical procedures, Walsh et al. identified $55 \mathrm{mmHg}$ as a threshold below which patients were at increased risk for both renal and myocardial injury. Importantly, even brief periods (1-5 min) below $55 \mathrm{mmHg}$ MAP were associated with an increased risk [53]. In a recent observational study, Salmasi et al. identified a threshold of $65 \mathrm{mmHg}$ or $20 \%$ decrease for $10-15 \mathrm{~min}$ from baseline, below which there is an increased risk of AKI and myocardial injury. Not surprisingly, the risk increased with lower thresholds and longer duration of hypotension [54]. The authors, however, found that association based on absolute thresholds was comparable to that based on relative thresholds, and no interaction with preoperative pressure was found. Hence, the authors concluded that anesthetic management should target an absolute MAP value greater than $65 \mathrm{mmHg}$ [54] regardless of baseline pressure. A recent multicenter randomized controlled trial (RCT) in septic shock patients compared two MAP levels $(65-70 \mathrm{mmHg}$ and $80-85 \mathrm{mmHg}$ ). In the overall population, no differences in mortality or renal outcomes were observed, with a higher incidence of atrial fibrillation in the highest target MAP group [55]. However, the authors found a lower incidence of AKI and need for RRT in chronically hypertensive patients when a MAP of $80-85 \mathrm{mmHg}$ was targeted [55]. As these results are derived from a subgroup analysis in a different clinical setting, generalization to vascular surgery patients remains to be determined. Furthermore, higher MAP levels may be associated with increased bleeding risk and disruption of vascular anastomosis. Hence, the optimal MAP target should be evaluated on a case-by-case basis together with the surgeon and may vary within the same surgical procedure.
Hypovolemia (both relative and absolute) is a well-known risk factor for AKI, and hypovolemic patients should receive adequate volume replacement. Unfortunately, volume overload has been associated to increased risk of AKI development too [56, 57]. A major issue remains therefore to accurately determine patient volume status. It is now well recognized that the absolute value of static parameters such as central venous pressure (CVP) and pulmonary capillary wedge pressure (PCWP) does not reliably predict fluid responsiveness [58], although CVP remains a good marker of preload and a key determinant of pressure gradient for organ perfusion (MAP-CVP) [59]. Dynamic indices of fluid responsiveness have shown better performance in predicting fluid responsiveness, but all have drawbacks which may limit their use in cardiovascular surgery (e.g., the need for absence of arrhythmias, high tidal volumes and lung compliance, closed chest, and continuous cardiac output monitoring) [59].

The choice of fluid to administer is also a critical issue. Fluids can be divided in crystalloids, artificial colloids, and natural colloids [60]. Until recently, it was believed that colloids, compared with crystalloids, had a better volume-expanding capacity (1 L colloid equivalent to $3 \mathrm{~L}$ crystalloids), which should theoretically translate in a more sustained hemodynamic effect with a reduced extravascular edema. However, recent trials demonstrated that actual colloid/crystalloid volume expansion ratio is probably less than 1:1.5 [60]. In addition, artificial colloids have been associated to several side effects, including allergic reactions, coagulation impairment, and, above all, nephrotoxicity [47, 61-63]. The largest multicenter RCT (mRCT) performed so far investigated the effect of hydroxyethyl starch (HES) in critically ill patients and showed increased mortality and AKI in HES-treated patients, as compared with crystalloids $[64,65]$. Accordingly, use of HES is currently contraindicated by international guidelines, while use of other artificial colloids is discouraged [47]. Some authors, nevertheless, suggest that the use of colloids (including HES) is safe in selected patients and following strict dosing and monitoring 
protocol [66]. Human albumin is the only colloid that has not been associated with increased risk of AKI, and safety in adults has been assessed in several mRCTs $[67,68]$, although an increased mortality associated with both 5\% human albumin and $0.9 \%$ saline fluid bolus in children with sepsis was found [69]. In summary, human albumin remains the most attractive colloid when hypooncotic hypovolemia is suspected, although the high costs may limit its use.

Among crystalloids, it has been suggested that large infusion of $0.9 \%$ saline may increase AKI risk due to the high chloride levels and subsequent acid-base and electrolyte equilibrium alterations. Although a clear effect has not been demonstrated in large mRCTs [70], it seems prudent and physiologically more rational to use balanced crystalloid solutions instead of $0.9 \%$ saline when large-volume resuscitation is required [32, 47].

\subsubsection{Specific Drugs}

\subsubsection{Dopamine}

Dopamine is an endogenous catecholamine with different effects on adrenergic receptors depending on dose. At doses $\leq 3 \mu \mathrm{g} / \mathrm{kg} / \mathrm{min}$, dopamine is considered to stimulate dopaminergic receptors only; between 4 and $10 \mu \mathrm{g} / \mathrm{kg} / \mathrm{min}$, it stimulates $\beta$-adrenergic receptors, increasing ino- and chronotropism, and in doses $>10 \mu \mathrm{g} / \mathrm{kg} / \mathrm{min}$, it has also $\alpha$-receptor-mediated vasoconstrictor effect. Low-dose dopamine $(\leq 3 \mu \mathrm{g} / \mathrm{kg} / \mathrm{min})$ has been advocated in the past to preserve renal blood flow through a selective afferent arteriolar vasodilation mediated by dopaminergic receptors [71]. Although low-dose dopamine may actually increase renal plasma flow, GFR, and sodium excretion, this effect seems to be attributable to increase in cardiac output, rather than specific effects on renal hemodynamics [71]. Some authors have even found that low-dose dopamine may actually worsen renal perfusion [72]. Finally both high-quality mRCTs and metaanalyses failed to demonstrate any effect of lowdose dopamine on incidence or clinical course of AKI or mortality [73, 74].
The use of dopamine as a vasopressor in shock has been investigated in a large mRCT comparing dopamine and norepinephrine [75]. Although no difference in mortality was observed between the two groups, dopamine use was associated with an increased risk of arrhythmias and a trend toward increased renal support-free days in the norepinephrine group. Furthermore, a subgroup analysis suggested a survival benefit in patients with cardiogenic shock receiving norepinephrine [75].

Therefore, there is no rationale to support use of low-dose dopamine to prevent or treat AKI, and current evidence also discourages the use of dopamine as first-line inotropic/vasopressor agent $[47,76,77]$.

\subsubsection{Fenoldopam}

Fenoldopam is a selective $\mathrm{D}_{1}$ dopamine receptor agonist which acts as a systemic and renal vasodilator. It has been shown to promote diuresis and natriuresis and to increase renal blood flow. Several meta-analyses of RCTs on fenoldopam use in cardiovascular and major surgery suggested a possible beneficial effect of fenoldopam on AKI development, but not on need for RRT or mortality [78-80]. Notably, most trials included in meta-analyses were small and considered at high risk of bias.

The largest mRCT performed on fenoldopam use so far randomized 667 post-cardiac surgery patients with RIFLE-R AKI to fenoldopam or placebo and found no difference in need for RRT or mortality [81]. Furthermore, fenoldopam use was associated with a higher incidence of hypotension.

Although there still may be room for future investigation on preventive use of fenoldopam (i.e., in high-risk patients before AKI development), current evidence does not support fenoldopam use in patients with or at risk for AKI [47]. This recommendation is further supported by the hypotensive effect of fenoldopam in light of the key role of MAP in kidney protection.

\subsubsection{Levosimendan}

Levosimendan is a calcium sensitizer with positive inotropic, vasodilatory, and cardioprotective effects [82, 83]. It has been suggested that levosimendan may enhance kidney protection through 
systemic and renal hemodynamics effects, as well as direct anti-ischemic, anti-inflammatory, and anti-apoptotic effects [84]. Promising results were indeed shown in meta-analyses of RCTs in patients with or at risk for AKI receiving levosimendan $[85,86]$. However, three recent mRCTs in cardiac surgery setting failed to demonstrate an improvement in renal outcome associated with levosimendan use, either as "prophylactic" measure in high-risk patients $[87,88]$ or as "therapeutic" measure in patients with established postoperative cardiovascular dysfunction [89].

Accordingly, use of levosimendan to treat or prevent AKI in cardiovascular surgery is currently not supported by randomized evidence. Nevertheless, levosimendan might still have a role in the preoperative optimization of patients with moderate-to-severe myocardial dysfunction. In this case, however, the optimal use would probably be to start levosimendan at least $6 \mathrm{~h}$ before surgery and ideally $24 \mathrm{~h}$ before.

\subsubsection{Vasopressin}

Vasopressin and its analogue terlipressin are potent non-catecholaminergic vasoconstrictors which improve systemic hemodynamics in catecholamine-resistant vasodilatory shock [90] and may improve GFR through post-glomerular vasoconstriction [91]. A large mRCT in septic patients did not show a beneficial effect on mortality or renal outcome of low-dose vasopressin in septic shock patients, as compared with norepinephrine [92]. However, a post hoc analysis of the same trial suggested that vasopressin could prevent AKI progression in patients with stage 1 AKI at baseline [93]. A subsequent $2 \times 2 \mathrm{mRCT}$ on vasopressin and steroids use in early septic shock, however, did not demonstrate a reduction in incidence or progression to stage $3 \mathrm{AKI}$ in vasopressin-treated patients [94]. Need for RRT was reduced but only in non-survivors. Another recent single-center RCT in post-cardiac surgery patients with vasodilatory shock compared vasopressin and norepinephrine as first-line vasopressor agent. Incidence of AKI and need for RRT was reduced in patients receiving vasopressin [95]; however, these findings require confirmation in high-quality mRCTs [47].
In summary, current evidence suggest that early use of vasopressin should be considered in patients requiring high-dose norepinephrine to maintain MAP.

\subsubsection{Diuretics}

Diuretics have been a mainstay of AKI treatment for years [96]. The hypothesized direct beneficial effects of diuretics (loop diuretics in particular) include the prevention of tubular obstruction, increase in renal blood flow, and reduction in oxygen consumption in the renal medulla. In addition, they might have an indirect beneficial effect by reducing volume overload and venous congestion.

Up to now, no perioperative RCT showed a convincing reduction in incidence, severity, or clinical course of AKI with diuretics administration [15, 47, 97-99].

Nevertheless, diuretics could still have a fundamental role in controlling fluid overload, which is associated with venous congestion and increased CVP, conditions that worsen renal perfusion and contribute to renal damage development.

Furthermore, a standardized furosemide stress test to predict AKI severity was recently developed and validated. Urinary output lower than $200 \mathrm{~mL} / 2 \mathrm{~h}$ after a $1-1.5 \mathrm{mg} / \mathrm{kg}$ furosemide bolus in oliguric patients was found to be associated to AKI progression to more severe stages [100]. Furosemide stress test in the setting of perioperative cardiovascular surgery remains to be validated. However, it is particularly attractive in this setting, especially during procedures involving renal arteries. In an oliguric patient who underwent a procedure on renal arteries, absence of an adequate diuretic response following the test should trigger further diagnostic work-up, such as ultrasound or angiographic assessment of renal vascular bed.

\subsubsection{Steroids}

Steroids are frequently administered in patients at risk for AKI with the aim of reducing inflammatory and ischemia-reperfusion injury. However, recent large mRCTs failed to demonstrate a protective effect of both methylprednisolone and dexamethasone on renal failure following cardiac 
surgery [101, 102]. Nevertheless, a post hoc analysis of one of the trials showed a reduction in need for RRT in patients receiving $1 \mathrm{mg} / \mathrm{kg}$ dexamethasone intraoperatively, particularly when eGFR was lower than $15 \mathrm{~mL} / \mathrm{min} / 1.73 \mathrm{~m}^{2}$ [103]. In addition, subgroup analyses of these trials suggested that steroids may have an age-dependent effect, being beneficial in patients aged $<65$ years and possibly harmful in patients aged $>80$ years [104]. However, these preliminary findings need to be confirmed and require further investigation.

\subsubsection{Statins}

Similarly to steroids, statins have anti-inflammatory, antioxidant, and antithrombotic effects (socalled pleiotropic effects) which may have a role in preventing perioperative kidney damage [105, 106]. Accordingly, perioperative administration of statins to improve cardiovascular and renal outcome has been investigated in large number of RCTs, especially in cardiovascular surgery setting. Unfortunately, contrary to expectation, recent trials in cardiac surgery found that perioperative statin administration was associated with an increased risk of AKI, particularly in statinnaïve patients [107-109]. A recent meta-analysis including these recent RCTs found a trend toward increase in mortality in patients receiving statins [110]. In vascular surgery, a recent meta-analysis highlighted lack of definitive evidence of beneficial effects of perioperative statin administration [111], as did a recent mRCT in noncardiac surgery [112]. According to results of these trials, statins should not be administered perioperatively in statin-naïve patients, while the management of statins in patients already receiving chronic therapy remains controversial, especially considering the possible detrimental effect of statin withdrawal due to rebound effect $[113,114]$. In the absence of trials addressing this issue, it seems prudent to continue statins perioperatively in patients already receiving a chronic statin therapy.

\subsubsection{Natriuretic Peptides}

Natriuretic peptides include atrial natriuretic peptide (ANP) and b-type natriuretic peptide (BNP), both released by cardiac myocytes in response to acute increase in stretch or pressure [115-117].
Both natriuretic peptides induce dilation of afferent and constriction of efferent arterioles, promotes an increase in glomerular filtration rate and sodium excretion, and has a dose-dependent hypotensive effect.

Several RCTs and meta-analyses of RCTs on perioperative administration of natriuretic peptides to prevent kidney damage have been published [118-122]. These studies found that administration of low-dose ANP might reduce incidence of AKI and RRT in cardiovascular surgery (at expense of a higher incidence of hypotension and arrhythmias), while high-dose ANP and BNP have no effect or may even be detrimental. However, a panel of expert from the European Society of Intensive Care Medicine also highlighted that published trials are of overall small sample size and low quality, and therefore routine perioperative administration of ANP cannot currently be recommended [47]

\subsubsection{N-Acetylcysteine}

$\mathrm{N}$-Acetylcysteine (NAC) is a glutathione precursor with antioxidant and free radical-scavenging properties. These properties have been suggested to have a kidney-protective effect from ischemiareperfusion injury and inflammatory damage. Accordingly NAC has been studied in a large number of RCTs performed in the setting of contrast-induced AKI and cardiac surgery patients [47]. As for many other interventions, RCT on perioperative NAC use in cardiac and vascular surgery showed controversial effects, with some trials reporting some beneficial effects [123, 124] and other a neutral effect [125-128]. If a benefit exists, it is probably limited to patients with a creatinine clearance $<60 \mathrm{~mL} / \mathrm{min}[123$, 124]. However, quality of evidence is considered low [47]. In addition, NAC is not devoid of side effects, such as anaphylactic and anaphylactoid reactions $[129,130]$.

\subsubsection{Future Directions}

Due to negative or controversial results of almost all interventions investigated so far, research on pharmacological strategies to treat or prevent AKI is still ongoing. Several agents have been suggested to be of potential benefit in patients 
with or at risk for AKI, including alkaline phosphatase, endothelin-A receptor antagonist, prostaglandins, and antioxidant vitamins such as vitamins $\mathrm{C}$ and $\mathrm{E}[6,51]$. Some promising results have been suggested in preclinical, observational, or phase II trials, and further trails are likely to be completed in the next years. Alkaline phosphatase at the most advanced stage of clinical investigation is being currently investigated in a phase II mRCT in septic patient (NCT02182440).

\subsubsection{Prevention of Contrast- Induced Acute Kidney Injury}

A major limitation of current evidence concerning CI-AKI prevention is that most of available trials were performed in the setting of coronary angiography, peripheral angiography, or diagnostic CT scan, which may be slightly different from major endovascular procedures (e.g., branchedfenestrated EVAR). Nevertheless, general recommendations should also apply to vascular surgery patients.

\subsubsection{Contrast Volume and Type}

There is a correlation between the risk of CI$\mathrm{AKI}$ and the volume of iodinated contrast media administered [131]. It has been found that a ratio $<1$ between grams of iodine ( $\mathrm{g}-\mathrm{I})$ and eGFR is safe in a patient without multiple risk factors; the risk of CI-AKI in this setting is $3 \%$, while it increase to $25 \%$ at a $\mathrm{g}-\mathrm{I} / \mathrm{eGFR}$ ratio $\geq 1$ [132].

Osmolarity of contrast media is also considered to have a role in CI-AKI development. In patients with normal renal function, low- and high-osmolar contrast media are considered to carry the same CI-AKI risk [133]. On the contrary, low-osmolar contrast media are considered less nephrotoxic than high-osmolar contrast in patients with pre-existing kidney function impairment, and in these patients, the use of iso- or lowosmolar contrast media is recommended [15, 43].

\subsubsection{Volume Expansion}

To date, volume expansion remains the only widely recognized strategy to prevent CI-AKI $[15,32,41,43]$. A common protocol for elective procedures may be administration of $1 \mathrm{~mL} / \mathrm{kg} / \mathrm{h}$ of $0.9 \%$ normal saline for $12 \mathrm{~h}$ before and $12 \mathrm{~h}$ after scheduled contrast administration. Other authors suggest administering $1 \mathrm{~L}$ over $12 \mathrm{~h}$ independently from patient weight [41]. For urgent procedures, a possible alternative might be $3 \mathrm{~mL} /$ $\mathrm{kg} / \mathrm{h}$ for $1 \mathrm{~h}$ before contrast administration and $1 \mathrm{~mL} / \mathrm{kg} / \mathrm{h}$ for $6 \mathrm{~h}$ after [134]. Others suggest using a $1 \mathrm{~L}$ glucose $5 \%+150 \mathrm{mmol} / \mathrm{L}$ sodium bicarbonate $8.4 \%$ instead of $0.9 \%$ normal saline for urgent procedures, with an infusion rate of $3 \mathrm{~mL} / \mathrm{kg} / \mathrm{h}$ (maximal rate $300 \mathrm{~mL} / \mathrm{h}$; reduce rate by half in heart failure patients) over $1 \mathrm{~h}$ before and $1 \mathrm{~mL} / \mathrm{kg} / \mathrm{h}$ (maximal rate $100 \mathrm{~mL} / \mathrm{h}$; reduce rate by half in heart failure patients) for $6 \mathrm{~h}$ after contrast administration [41]. Infusion rate should be reduced, and careful monitoring is recommended for patients who may not tolerate excessive volume expansion (e.g., advanced heart failure). Low- and intermediate-risk patients may receive oral fluid administration only [41], although evidence is controversial. On the contrary, high-risk patients should receive intravenous volume expansion [41]. While suggested by some authors, the effectiveness of sodium bicarbonate on CI-AKI in high-risk patients remains uncertain. Accordingly, guidelines from different societies provided different recommendations regarding sodium bicarbonate use as volume expansion [32, 134]. However, two recent mRCT challenged this view, showing no difference in CI-AKI incidence between patients with GRF $<60 \mathrm{~mL} / \mathrm{min}$ receiving intravenous $0.9 \%$ normal saline $(1 \mathrm{~mL} / \mathrm{kg} / \mathrm{h}$ for $12 \mathrm{~h}$ before and after contrast exposure) and patients receiving no hydration [135] and no difference in CI-AKI incidence between patients receiving sodium bicarbonate versus $0.9 \%$ normal saline and $\mathrm{N}$-acetylcysteine versus placebo [136].

Recently, some randomized trials have shown some beneficial effect of forced diuresis with furosemide administration and matched hydration using an automated fluid delivery system [137]. In a meta-analysis of RCTs, incidence of CI-AKI and post-procedural need for RRT were reduced when contrast media was administered after a diuresis of $300 \mathrm{~mL} / \mathrm{h}$ using was achieved [137]. However, all trials included in 
this meta-analysis were considered at high risk of bias, and further investigation on automated fluid delivery devices is required. Of note, there is agreement that urgent or emergent diagnostic or therapeutic interventions should not be delayed solely to perform volume expansion for CI-AKI prevention.

\subsubsection{Pharmacological Intervention}

A wide number of pharmacological interventions to prevent CI-AKI have been investigated, with only few of them showing high-quality evidence of benefit [41, 43, 47, 138]. The two strategies which showed the most convincing effect are $\mathrm{N}$-acetylcysteine (NAC) and statin administration.

A lot of study demonstrated renoprotective effects of NAC prophylaxis once AKI is administered before the onset of renal insult due to the antioxidant properties [139]. In a recent meta-analysis, NAC plus saline showed superior effect as compared with normal saline in patients receiving low-osmolar contrast media [138]. Considering the possible side effects of intravenous NAC, KDIGO guidelines suggest using oral NAC together with saline in patients at high risk for CI-AKI with a very low level of evidence [134], while other authors do not recommend such strategy $[32,41]$.

We described earlier the possible kidney-protective effects of statins due to their pleiotropic effects. Current evidence from RCTs performed in the setting of coronary angiography suggests that short-term use of atorvastatin or rosuvastatin may reduce incidence of CI-AKI [47]. These findings were confirmed in a meta-analysis of RCT showing beneficial effect in CI-AKI prevention of a regimen of statins plus NAC plus saline over NAC plus saline alone [138]. Accordingly, periprocedural statin administration may be considered in high-risk patients undergoing contrast media administration. However, to further complicate the clinical picture, perioperative statin administration showed detrimental effect in patients undergoing cardiac surgery [137]. Statin administration in statin-naïve patients should be therefore carefully considered in patients undergoing major cardiovascular surgery, even if contrast media administration is planned. On the contrary, patients undergoing diagnostic or therapeutic endovascular procedures may benefit from statins, although these will require further investigation. Notably, most patients scheduled for vascular surgery are likely to already receive statins as part of their chronic medical therapy.

\section{References}

1. Bellomo R, Kellum JA, Ronco C. Acute kidney injury. Lancet. 2012;380(9843):756-66. https://doi. org/10.1016/S0140-6736(11)61454-2.

2. Chertow GM, Burdick E, Honour M, Bonventre JV, Bates DW. Acute kidney injury, mortality, length of stay, and costs in hospitalized patients. J Am Soc Nephrol. 2005;16(11):3365-70.

3. Zeng X, McMahon GM, Brunelli SM, Bates DW, Waikar SS. Incidence, outcomes, and comparisons across definitions of AKI in hospitalized individuals. Clin J Am Soc Nephrol. 2014;9(1):12-20. https://doi. org/10.2215/CJN.02730313.

4. Wang HE, Muntner P, Chertow GM, Warnock DG. Acute kidney injury and mortality in hospitalized patients. Am J Nephrol. 2012;35(4):349-55. https:// doi.org/10.1159/000337487.

5. Doyle J, Forni L. Acute kidney injury: short-term and long-term effects. Crit Care. 2016;20:188.

6. Bellomo R, Ronco C, Mehta RL, Asfar P, BoisraméHelms J, Darmon M, et al. Acute kidney injury in the ICU: from injury to recovery: reports from the 5th Paris International Conference. Ann Intensive Care. 2017;7(1):49. https://doi.org/10.1186/ s13613-017-0260-y.

7. Lewington AJ, Cerdá J, Mehta RL. Raising awareness of acute kidney injury: a global perspective of a silent killer. Kidney Int. 2013;84(3):457-67. https://doi. org/10.1038/ki.2013.153.

8. Mehta RL, Cerdá J, Burdmann EA, Tonelli M, García-García G, Jha V, et al. International Society of Nephrology's 0by25 initiative for acute kidney injury (zero preventable deaths by 2025): a human rights case for nephrology. Lancet. 2015;385(9987):261643. https://doi.org/10.1016/S0140-6736(15)60126-X.

9. Wonnacott A, Meran S, Amphlett B, Talabani B, Phillips A. Epidemiology and outcomes in community-acquired versus hospital-acquired AKI. Clin J Am Soc Nephrol. 2014;9(6):1007-14. https://doi. org/10.2215/CJN.07920713.

10. Kellum JA, Lameire N, KDIGO AKI Guideline Work Group. Diagnosis, evaluation, and management of acute kidney injury: a KDIGO summary (part 1). Crit Care. 2013;17(1):204. https://doi.org/10.1186/ cc11454. 
11. Grams ME, Sang Y, Coresh J, Ballew S, Matsushita K, Molnar MZ, et al. Acute kidney injury after major surgery: a retrospective analysis of veterans health administration data. Am J Kidney Dis. 2016;67(6):872-80. https://doi.org/10.1053/j.ajkd.2015.07.022.

12. Bellomo R, Ronco C, Kellum JA, Mehta RL, Palevsky P, Acute Dialysis Quality Initiative Work Group. Acute renal failure - definition, outcome measures, animal models, fluid therapy and information technology needs: the second international consensus conference of the acute dialysis quality initiative (ADQI) group. Crit Care. 2004;8(4):R204-12.

13. Mehta RL, Kellum JA, Shah SV, Molitoris BA, Ronco C, Warnock DG, et al. Acute kidney injury network: report of an initiative to improve outcomes in acute kidney injury. Crit Care. 2007;11(2):R31. https://doi. org/10.1186/cc5713.

14. Lassnigg A, Schmidlin D, Mouhieddine M, Bachmann LM, Druml W, Bauer P, et al. Minimal changes of serum creatinine predict prognosis in patients after cardiothoracic surgery: a prospective cohort study. J Am Soc Nephrol. 2004;15(6):1597-605.

15. Kidney Disease: Improving Global Outcomes (KDIGO) Acute Kidney Injury Work Group. KDIGO clinical practice guideline for acute kidney injury. Kidney Int Suppl. 2012;2:1-138.

16. Twine CP, Boyle JR. Renal dysfunction after EVAR: time for a standard definition. J Endovasc Ther. 2013;20(3):331-3. https://doi. org/10.1583/12-4104C.1.

17. Coselli JS, LeMaire SA, Preventza O, de la Cruz KI, Cooley DA, Price MD, et al. Outcomes of 3309 thoracoabdominal aortic aneurysm repairs. J Thorac Cardiovasc Surg. 2016;151(5):1323-37. https://doi. org/10.1016/j.jtcvs.2015.12.050.

18. Tshomba Y, Kahlberg A, Melissano G, Coppi G, Marone E, Ferrari D, et al. Comparison of renal perfusion solutions during thoracoabdominal aortic aneurysm repair. J Vasc Surg. 2014;59(3):623-33. https:// doi.org/10.1016/j.jvs.2013.09.055.

19. Wynn MM, Acher C, Marks E, Engelbert T, Acher CW. Postoperative renal failure in thoracoabdominal aortic aneurysm repair with simple cross-clamp technique and $4^{\circ} \mathrm{C}$ renal perfusion. J Vasc Surg. 2015;61(3):611-22. https://doi.org/10.1016/j. jvs.2014.10.040.

20. Roh GU, Lee JW, Nam SB, Lee J, Choi JR, Shim $\mathrm{YH}$. Incidence and risk factors of acute kidney injury after thoracic aortic surgery for acute dissection. Ann Thorac Surg. 2012;94(3):766-71. https://doi. org/10.1016/j.athoracsur.2012.04.057.

21. Tsai HS, Tsai FH, Chen YC, Wu ML, Chen SW, Chu JJ, et al. Impact of acute kidney injury on oneyear survival after surgery for aortic dissection. Ann Thorac Surg. 2012;94:1407-12.

22. Sasabuchi Y, Kimura N, Shiotsuka J, Komuro T, Mouri $\mathrm{H}$, Ohnuma T, et al. Long-term survival in patients with acute kidney injury after acute type a aortic dissection repair. Ann Thorac Surg. 2016;102(6):2003-9. https:// doi.org/10.1016/j.athoracsur.2016.05.006.
23. Dariane C, Coscas R, Boulitrop C, Javerliat I, Vilaine E, Goeau-Brissonniere $\mathrm{O}$, et al. Acute kidney injury after open repair of intact abdominal aortic aneurysms. Ann Vasc Surg. 2017;39:294-300. https://doi. org/10.1016/j.avsg.2016.09.010.

24. Kopolovic I, Simmonds K, Duggan S, Ewanchuk M, Stollery DE, Bagshaw SM, et al. Risk factors and outcomes associated with acute kidney injury following ruptured abdominal aortic aneurysm. BMC Nephrol. 2013;14:99. https://doi. org/10.1186/1471-2369-14-99.

25. van Beek SC, Legemate DA, Vahl A, Wisselink W, Barnes M, Fitridge RA, et al. External validation of the Endovascular aneurysm repair Risk Assessment model in predicting survival, reinterventions, and endoleaks after endovascular aneurysm repair. J Vasc Surg. 2014;59(6):1555-1561.e1. https://doi. org/10.1016/j.jvs.2013.12.043.

26. Jalalzadeh $H$, Indrakusuma R, Vogt L, van Beek SC, Vahl AC, Wisselink W, et al. Long-term survival after acute kidney injury following ruptured abdominal aortic aneurysm repair. J Vasc Surg. 2017;66(6):1712. e2-8.e2. https://doi.org/10.1016/j.jvs.2017.04.049.

27. Piffaretti G, Benedetto F, Menegolo M, Antonello M, Tarallo A, Grego F. Outcomes of endovascular repair for blunt thoracic aortic injury. J Vasc Surg. 2013;6:1483-9. https://doi.org/10.1016/j. jvs.2013.05.096.

28. Drews JD, Patel HJ, Williams DM, Dasika NL, Deeb GM. The impact of acute renal failure on early and late outcomes after thoracic aortic endovascular repair. Ann Thorac Surg. 2014;97(6):2027-33. https:// doi.org/10.1016/j.athoracsur.2014.02.045.

29. Jeon $\mathrm{YH}, \mathrm{Bae} \mathrm{CH}$. The risk factors and outcomes of acute kidney injury after thoracic endovascular aortic repair. Korean J Thorac Cardiovasc Surg. 2016;49(1):15-21. https://doi.org/10.5090/ kjtcs.2016.49.1.15.

30. Luo S, Ding H, Luo J, Li W, Ning B, Liu Y, et al. Risk factors and early outcomes of acute renal injury after thoracic aortic endograft repair for type B aortic dissection. Ther Clin Risk Manag. 2017;13:1023-9. https://doi.org/10.2147/TCRM.S131456.

31. Jhaveri KD, Saratzis AN, Wanchoo R, Sarafidis PA. Endovascular aneurysm repair (EVAR)- and transcatheter aortic valve replacement (TAVR)-associated acute kidney injury. Kidney Int. 2017;91(6):1312-23. https://doi.org/10.1016/j.kint.2016.11.030.

32. Ichai C, Vinsonneau C, Souweine B, Armando F, Canet E, Clec'h C, et al. Acute kidney injury in the perioperative period and in intensive care units (excluding renal replacement therapies). Ann Intensive Care. 2016;6(1):48. https://doi.org/10.1186/ s13613-016-0145-5.

33. Thakar CV, Arrigain S, Worley S, Yared JP, Paganini EP. A clinical score to predict acute renal failure after cardiac surgery. J Am Soc Nephrol. 2005;16(1):162-8.

34. Mehta RH, Grab JD, O'Brien SM, Bridges CR, Gammie JS, Haan CK, Society of Thoracic Surgeons National Cardiac Surgery Database Investigators, 
et al. Bedside tool for predicting the risk of postoperative dialysis in patients undergoing cardiac surgery. Circulation. 2006;114(21):2208-16.. quiz 2208.

35. Chertow GM, Lazarus JM, Christiansen CL, Cook EF, Hammermeister KE, Grover F, et al. Preoperative renal risk stratification. Circulation. 1997;95(4): 878-84.

36. Wijeysundera DN, Karkouti K, Dupuis JY, Rao V, Chan CT, Granton JT, et al. Derivation and validation of a simplified predictive index for renal replacement therapy after cardiac surgery. JAMA. 2007;297(16):1801-9.

37. Brown JR, Cochran RP, Leavitt BJ, Dacey LJ, Ross CS, MacKenzie TA, et al. Multivariable prediction of renal insufficiency developing after cardiac surgery. Circulation. 2007;116(11 Suppl):I139-43. https://doi. org/10.1161/CIRCULATIONAHA.106.677070.

38. Pannu N, Graham M, Klarenbach S, Meyer S, Kieser T, Hemmelgarn B, et al. A new model to predict acute kidney injury requiring renal replacement therapy after cardiac surgery. CMAJ. 2016;188(15):1076-83.

39. Palomba H, de Castro I, Neto AL, Lage S, Yu L. Acute kidney injury prediction following elective cardiac surgery: AKICS score. Kidney Int. 2007;72(5):624-31.

40. Jorge-Monjas P, Bustamante-Munguira J, Lorenzo M, Heredia-Rodríguez M, Fierro I, Gómez-Sánchez E, et al. Predicting cardiac surgery-associated acute kidney injury: the CRATE score. J Crit Care. 2016;31(1):130-8. jcrc.2015.11.004.

41. Vanmassenhove J, Kielstein J, Jörres A, Biesen WV. Management of patients at risk of acute kidney injury. Lancet. 2017;389(10084):2139-51. https:// doi.org/10.1016/S0140-6736(17)31329-6.

42. Kristovic D, Horvatic I, Husedzinovic I, Sutlic Z, Rudez I, Baric D, et al. Cardiac surgery-associated acute kidney injury: risk factors analysis and comparison of prediction models. Interact Cardiovasc Thorac Surg. 2015;21(3):366-73. https://doi.org/10.1093/ icvts/ivv162.

43. Wong GT, Lee EY, Irwin MG. Contrast induced nephropathy in vascular surgery. $\mathrm{Br} \mathrm{J}$ Anaesth. 2016;117(Suppl 2):ii63-73. https://doi.org/10.1093/ bja/aew213.

44. Lameire N, Adam A, Becker CR, Davidson C, McCullough PA, Stacul F, et al. Baseline renal function screening. Am J Cardiol. 2006;98(6A):21K-6K. https://doi.org/10.1016/j.amjcard.2006.01.021.

45. Brown JR, McCullough PA, Splaine ME, Davies L, Ross CS, Dauerman HL, et al. How do centres begin the process to prevent contrast-induced acute kidney injury: a report from a new regional collaborative. BMJ Qual Saf. 2012;21(1):54-62. https://doi. org/10.1136/bmjqs-2011-000041.

46. Mehran R, Aymong ED, Nikolsky E, Lasic Z, Iakovou I, Fahy M, et al. A simple risk score for prediction of contrast-induced nephropathy after percutaneous coronary intervention: development and initial validation. J Am Coll Cardiol. 2004;44(7):1393-9.
47. Joannidis M, Druml W, Forni LG, Groeneveld ABJ, Honore PM, Hoste E, et al. Prevention of acute kidney injury and protection of renal function in the intensive care unit: update 2017: expert opinion of the Working Group on Prevention, AKI section, European Society of Intensive Care Medicine. Intensive Care Med. 2017;43(6):730-49. https://doi.org/10.1007/ s00134-017-4832-y.

48. Landoni G, Bove T, Székely A, Comis M, Rodseth RN, Pasero D, et al. Reducing mortality in acute kidney injury patients: systematic review and international web-based survey. J Cardiothorac Vasc Anesth. 2013;27(6):1384-98. https://doi.org/10.1053/j. jvca.2013.06.028.

49. Kane-Gill SL, Goldstein SL. Drug-induced acute kidney injury: a focus on risk assessment for prevention. Crit Care Clin. 2015;31(4):675-84. https://doi. org/10.1016/j.ccc.2015.06.005.

50. Sousa-Uva M, Head SJ, Milojevic M, Collet JP, Landoni G, Castella M, et al. 2017 EACTS Guidelines on perioperative medication in adult cardiac surgery. Eur J Cardiothorac Surg. 2018;53:5-33. https://doi. org/10.1093/ejcts/ezx314.

51. Di Tomasso N, Monaco F, Landoni G. Renal protection in cardiovascular surgery. F1000Research. 2016;5:331. f1000research.7348.1.

52. Wilhelm-Leen E, Montez-Rath ME, Chertow G. Estimating the risk of radiocontrast-associated nephropathy. J Am Soc Nephrol. 2017;28(2):653-9. https://doi.org/10.1681/ASN.2016010021.

53. Walsh M, Devereaux PJ, Garg AX, Kurz A, Turan A, Rodseth RN, et al. Relationship between intraoperative mean arterial pressure and clinical outcomes after noncardiac surgery: toward an empirical definition of hypotension. Anesthesiology. 2013;119(3):507-15. https://doi.org/10.1097/ALN.0b013e3182a10e26.

54. Salmasi V, Maheshwari K, Yang D, Mascha EJ, Singh A, Sessler DI, et al. Relationship between intraoperative hypotension, defined by either reduction from baseline or absolute thresholds, and acute kidney and myocardial injury after noncardiac surgery: a retrospective cohort analysis. Anesthesiology. 2017;126(1):47-65.

55. Asfar P, Meziani F, Hamel JF, Grelon F, Megarbane B, Anguel N, et al. High versus low blood-pressure target in patients with septic shock. N Engl J Med. 2014;370(17):1583-93. https://doi.org/10.1056/ NEJMoa1312173.

56. Bouchard J, Soroko SB, Chertow GM, Himmelfarb J, Ikizler TA, Paganini EP, et al. Fluid accumulation, survival and recovery of kidney function in critically ill patients with acute kidney injury. Kidney Int. 2009;76(4):422-7. https://doi.org/10.1038/ ki.2009.159.

57. Payen D, de Pont AC, Sakr Y, Spies C, Reinhart K, Vincent JL, et al. A positive fluid balance is associated with a worse outcome in patients with acute renal failure. Crit Care. 2008;12(3):R74. https://doi. org/10.1186/cc6916. 
58. Marik PE, Cavallazzi R. Does the central venous pressure predict fluid responsiveness? An updated metaanalysis and a plea for some common sense. Crit Care Med. 2013;41(7):1774-81. https://doi.org/10.1097/ CCM.0b013e31828a25fd.

59. Monnet X, Cipriani F, Camous L, Sentenac P, Dres M, Krastinova E, et al. The passive leg raising test to guide fluid removal in critically ill patients. Ann Intensive Care. 2016;6(1):46. https://doi.org/10.1186/ s13613-016-0149-1.

60. Myburgh JA, Mythen MG. Resuscitation fluids. N Engl J Med. 2013;369(13):1243-51. https://doi. org/10.1056/NEJMra1208627.

61. Pisano A, Landoni G, Bellomo R. The risk of infusing gelatin? Die-hard misconceptions and forgotten (or ignored) truths. Minerva Anestesiol. 2016;82(10):1107-14.

62. Mailloux L, Swartz CD, Capizzi R, Kim KE, Onesti $\mathrm{G}$, Ramirez $\mathrm{O}$, et al. Acute renal failure after administration of low-molecular weight dextran. N Engl J Med. 1967;277(21):1113-8.

63. Laxenaire MC, Charpentier C, Feldman L. Anaphylactoid reactions to colloid plasma substitutes: incidence, risk factors, mechanisms. A French multicenter prospective study. Ann Fr Anesth Reanim. 1994;13(3):301-10.

64. Perner A, Haase N, Guttormsen AB, Tenhunen J, Klemenzson G, Åneman A, et al. Hydroxyethyl starch 130/0.42 versus Ringer's acetate in severe sepsis. N Engl J Med. 2012;367(2):124-34. https://doi. org/10.1056/NEJMoa1204242.

65. Myburgh JA, Finfer S, Bellomo R, Billot L, Cass A, Gattas D, et al. Hydroxyethyl starch or saline for fluid resuscitation in intensive care. N Engl J Med. 2012;367(20):1901-11. https://doi.org/10.1056/ NEJMoa1209759.. Erratum. N Engl J Med. 2016;374(13):1298.

66. Meybohm P, Van Aken H, De Gasperi A, De Hert S, Della Rocca G, Girbes AR, et al. Re-evaluating currently available data and suggestions for planning randomised controlled studies regarding the use of hydroxyethyl starch in critically ill patients - a multidisciplinary statement. Crit Care. 2013;17(4):R166. https://doi.org/10.1186/cc12845.

67. Finfer S, Bellomo R, Boyce N, French J, Myburgh J, Norton R. A comparison of albumin and saline for fluid resuscitation in the intensive care unit. $\mathrm{N}$ Engl $\mathrm{J}$ Med. 2004;350(22):2247-56.

68. Caironi P, Tognoni G, Masson S, Fumagalli R, Pesenti A, Romero M, et al. Albumin replacement in patients with severe sepsis or septic shock. N Engl J Med. 2014;370(15):1412-21. https://doi.org/10.1056/ NEJMoa1305727.

69. Maitland K, Kiguli S, Opoka RO, Engoru C, OlupotOlupot P, Akech SO, et al. Mortality after fluid bolus in African children with severe infection. N Engl J Med. 2011;364(26):2483-95. https://doi.org/10.1056/ NEJMoa1101549.

70. Young P, Bailey M, Beasley R, SPLIT Investigators; ANZICS CTG, et al. Effect of a buffered crystal- loid solution vs saline on acute kidney injury among patients in the intensive care unit: the SPLIT randomized clinical trial. JAMA. 2015;314(16):1701-10. https://doi.org/10.1001/jama.2015.12334.

71. Jones D, Bellomo R. Renal-dose dopamine: from hypothesis to paradigm to dogma to myth and, finally, superstition? J Intensive Care Med. 2005;20(4):199211. https://doi.org/10.1177/0885066605276963.

72. Lauschke A, Teichgräber UK, Frei U, Eckardt KU. 'Low-dose' dopamine worsens renal perfusion in patients with acute renal failure. Kidney Int. 2006;69(9):1669-74. https://doi.org/10.1038/ sj.ki.5000310.

73. Friedrich JO, Adhikari N, Herridge MS, Beyene J. Meta-analysis: low-dose dopamine increases urine output but does not prevent renal dysfunction or death. Ann Intern Med. 2005;142(7):510-24.

74. Karthik S, Lisbon A. Low-dose dopamine in the intensive care unit. Semin Dial. 2006;19(6):465-71. https://doi.org/10.1111/j.1525-139X.2006.00208.x.

75. De Backer D, Biston P, Devriendt J, Madl C, Chochrad D, Aldecoa C, et al. Comparison of dopamine and norepinephrine in the treatment of shock. N Engl J Med. 2010;362(9):779-89. https://doi.org/10.1056/ NEJMoa0907118.

76. Rhodes A, Evans LE, Alhazzani W, Levy MM, Antonelli M, Ferrer R, et al. Surviving sepsis campaign: international guidelines for management of sepsis and septic shock: 2016. Intensive Care Med. 2017;43(3):304-77. https://doi.org/10.1007/ s00134-017-4683-6.

77. Møller MH, Claudius C, Junttila E, Haney M, Oscarsson-Tibblin A, Haavind A, et al. Scandinavian SSAI clinical practice guideline on choice of first-line vasopressor for patients with acute circulatory failure. Acta Anaesthesiol Scand. 2016;60(10):1347-66. https://doi.org/10.1111/aas.12780.

78. Landoni G, Biondi-Zoccai G, Marino G, Bove T, Fochi O, Maj G, et al. Fenoldopam reduces the need for renal replacement therapy and in-hospital death in cardiovascular surgery: a meta-analysis. J Cardiothorac Vasc Anesth. 2008;22(1):27-33. https:// doi.org/10.1053/j.jvca.2007.07.015.

79. Zangrillo A, Biondi-Zoccai GG, Frati E, Covello RD, Cabrini L, Guarracino F, et al. Fenoldopam and acute renal failure in cardiac surgery: a meta-analysis of randomized placebo-controlled trials. J Cardiothorac Vasc Anesth. 2012;26(3):407-13. https://doi. org/10.1053/j.jvca.2012.01.038.

80. Gillies MA, Kakar V, Parker RJ, Honoré PM, Ostermann M. Fenoldopam to prevent acute kidney injury after major surgery-a systematic review and meta-analysis. Crit Care. 2015;19:449. https://doi. org/10.1186/s13054-015-1166-4.

81. Bove T, Zangrillo A, Guarracino F, Alvaro G, Persi B, Maglioni E, et al. Effect of fenoldopam on use of renal replacement therapy among patients with acute kidney injury after cardiac surgery: a randomized clinical trial. JAMA. 2014;312(21):2244-53. https:// doi.org/10.1001/jama.2014.13573. 
82. Papp Z, Édes I, Fruhwald S, De Hert SG, Salmenperä M, Leppikangas H, et al. Levosimendan: molecular mechanisms and clinical implications: consensus of experts on the mechanisms of action of levosimendan. Int J Cardiol. 2012;159(2):82-7. https://doi. org/10.1016/j.ijcard.2011.07.022.

83. Farmakis D, Alvarez J, Gal TB, Brito D, Fedele F, Fonseca $\mathrm{C}$, et al. Levosimendan beyond inotropy and acute heart failure: evidence of pleiotropic effects on the heart and other organs: an expert panel position paper. Int J Cardiol. 2016;222:303-12. https://doi. org/10.1016/j.ijcard.2016.07.202.

84. Yilmaz MB, Grossini E, Silva Cardoso JC, Édes I, Fedele F, Pollesello P, et al. Renal effects of levosimendan: a consensus report. Cardiovasc Drugs Ther. 2013;27(6):581-90. https://doi.org/10.1007/ s10557-013-6485-6.

85. Bove T, Matteazzi A, Belletti A, Paternoster G, Saleh O, Taddeo D, et al. Beneficial impact of levosimendan in critically ill patients with or at risk for acute renal failure: a meta-analysis of randomized clinical trials. Heart Lung Vessel. 2015;7(1):35-46.

86. Zhou C, Gong J, Chen D, Wang W, Liu M, Liu B. Levosimendan for prevention of acute kidney injury after cardiac surgery: a meta-analysis of randomized controlled trials. Am J Kidney Dis. 2016;67(3):408-16. https://doi.org/10.1053/j. ajkd.2015.09.015.

87. Mehta RH, Leimberger JD, van Diepen S, Meza J, Wang A, Jankowich R, Harrison RW, Hay D, Fremes S, Duncan A, Soltesz EG, Luber J, Park S, Argenziano M, Murphy E, Marcel R, Kalavrouziotis D, Nagpal D, Bozinovski J, Toller W, Heringlake M, Goodman SG, Levy JH, Harrington RA, Anstrom KJ, Alexander JH, LEVO-CTS Investigators. Levosimendan in patients with left ventricular dysfunction undergoing cardiac surgery. N Engl J Med. 2017;376:2032-42. https://doi.org/10.1056/ NEJMoa1616218.

88. Cholley B, Caruba T, Grosjean S, Amour J, Ouattara A, Villacorta J, et al. Effect of Levosimendan on low cardiac output syndrome in patients with low ejection fraction undergoing coronary artery bypass grafting with cardiopulmonary bypass: the LICORN randomized clinical trial. JAMA. 2017;318(6):548-56. https://doi.org/10.1001/jama.2017.9973.

89. Landoni G, Lomivorotov VV, Alvaro G, Lobreglio R, Pisano A, Guarracino F, et al. Levosimendan for hemodynamic support after cardiac surgery. N Engl J Med. 2017;376(21):2021-31. https://doi.org/10.1056/ NEJMoa1616325.

90. Russell JA. Bench-to-bedside review: Vasopressin in the management of septic shock. Crit Care. 2011;15(4):226. https://doi.org/10.1186/cc8224.

91. Bragadottir G, Redfors B, Nygren A, Sellgren J, Ricksten SE. Low-dose vasopressin increases glomerular filtration rate, but impairs renal oxygenation in post-cardiac surgery patients. Acta Anaesthesiol Scand. 2009;53(8):1052-9. https://doi. org/10.1111/j.1399-6576.2009.02037.x.
92. Russell JA, Walley KR, Singer J, Gordon AC, Hébert PC, Cooper DJ. Vasopressin versus norepinephrine infusion in patients with septic shock. N Engl J Med. 2008;358(9):877-87. https://doi.org/10.1056/ NEJMoa067373.

93. Gordon AC, Russell JA, Walley KR, Singer J, Ayers $\mathrm{D}$, Storms MM, et al. The effects of vasopressin on acute kidney injury in septic shock. Intensive Care Med. 2010;36(1):83-91. https://doi.org/10.1007/ s00134-009-1687-x.

94. Gordon AC, Mason AJ, Thirunavukkarasu N, Perkins GD, Cecconi M, Cepkova M, et al. Effect of early vasopressin vs norepinephrine on kidney failure in patients with septic shock: the VANISH randomized clinical trial. JAMA. 2016;316(5):509-18. https://doi.org/10.1001/jama.2016.10485.

95. Hajjar LA, Vincent JL, Barbosa Gomes Galas FR, Rhodes A, Landoni G, Osawa EA, et al. Vasopressin versus norepinephrine in patients with vasoplegic shock after cardiac surgery: the VANCS randomized controlled trial. Anesthesiology. 2017;126(1):85-93. https://doi.org/10.1097/ ALN.0000000000001434.

96. Bagshaw SM, Delaney A, Jones D, Ronco C, Bellomo R. Diuretics in the management of acute kidney injury: a multinational survey. Contrib Nephrol. 2007;156:236-49. https://doi. org/10.1159/000102089.

97. Ho KM, Power BM. Benefits and risks of furosemide in acute kidney injury. Anaesthesia. 2010;65(3):283-93. https://doi. org/10.1111/j.1365-2044.2009.06228.x.

98. Bagshaw SM, Delaney A, Haase M, Ghali WA, Bellomo R. Loop diuretics in the management of acute renal failure: a systematic review and metaanalysis. Crit Care Resusc. 2007;9(1):60-8.

99. Sampath S, Moran JL, Graham PL, Rockliff S, Bersten AD, Abrams KR. The efficacy of loop diuretics in acute renal failure: assessment using Bayesian evidence synthesis techniques. Crit Care Med. 2007;35(11):2516-24.

100. Koyner JL, Davison DL, Brasha-Mitchell E, Chalikonda DM, Arthur JM, Shaw AD, Tumlin JA, Trevino SA, Bennett MR, Kimmel PL, Seneff MG, Chawla LS. Furosemide stress test and biomarkers for the prediction of AKI severity. J Am Soc Nephrol. 2015;26:2023-31. https://doi.org/10.1681/ ASN.2014060535.

101. Dieleman JM, Nierich AP, Rosseel PM, van der Maaten JM, Hofland J, Diephuis JC, et al. Intraoperative high-dose dexamethasone for cardiac surgery: a randomized controlled trial. JAMA. 2012;308(17):1761-7. https://doi.org/10.1001/ jama.2012.14144.

102. Whitlock RP, Devereaux PJ, Teoh KH, Lamy A, Vincent J, Pogue J, et al. Methylprednisolone in patients undergoing cardiopulmonary bypass (SIRS): a randomised, double-blind, placebo-controlled trial. Lancet. 2015;386(10000):1243-53. https://doi.org/10.1016/S0140-6736(15)00273-1. 
103. Jacob KA, Leaf D, Dieleman J, van Dijk D, Nierich $\mathrm{AP}$, Rosseel PM, et al. Intraoperative high-dose dexamethasone and severe AKI after cardiac surgery. J Am Soc Nephrol. 2015;26(12):2947-51. https://doi.org/10.1681/ASN.2014080840.

104. Dieleman JM, van Dijk D. Corticosteroids for cardiac surgery: a summary of two large randomised trials. Neth J Crit Care. 2016;24:6-10.

105. Kavalipati N, Shah J, Ramakrishan A, Vasnawala H. Pleiotropic effects of statins. Indian J Endocrinol Metab. 2015;19:554-62. https://doi. org/10.4103/2230-8210.163106.

106. Galyfos G, Sianou A, Filis K. Pleiotropic effects of statins in the perioperative setting. Ann Card Anaesth. 2017;20(Supplement):S43-8. https://doi. org/10.4103/0971-9784.197796.

107. Billings FT 4th, Hendricks PA, Schildcrout JS, Shi Y, Petracek MR, Byrne JG, Brown NJ. High-dose perioperative atorvastatin and acute kidney injury following cardiac surgery: a randomized clinical trial. JAMA. 2016;315:877-88. https://doi.org/10.1001/ jama.2016.0548.

108. Park JH, Shim JK, Song JW, Soh S, Kwak YL. Effect of atorvastatin on the incidence of acute kidney injury following valvular heart surgery: a randomized, placebo-controlled trial. Intensive Care Med. 2016;42(9):1398-407. https://doi.org/10.1007/ s00134-016-4358-8.

109. Zheng Z, Jayaram R, Jiang L, Emberson J, Zhao Y, Li Q, et al. Perioperative rosuvastatin in cardiac surgery. N Engl J Med. 2016;374(18):1744-53. https:// doi.org/10.1056/NEJMoa1507750.

110. Putzu A, Capelli B, Belletti A, Cassina T, Ferrari E, Gallo M, et al. Perioperative statin therapy in cardiac surgery: a meta-analysis of randomized controlled trials. Crit Care. 2016;20(1):395. https://doi. org/10.1186/s13054-016-1560-6.

111. Sanders RD, Nicholson A, Lewis SR, Smith AF, Alderson P. Perioperative statin therapy for improving outcomes during and after noncardiac vascular surgery. Cochrane Database Syst Rev. 2013;7:CD009971. https://doi. org/10.1002/14651858.CD009971.pub2.

112. Berwanger O, de Barros E, Silva PG, Barbosa RR, Precoma DB, Figueiredo EL, Hajjar LA, et al. Atorvastatin for high-risk statin-naïve patients undergoing noncardiac surgery: the lowering the risk of operative complications using atorvastatin loading dose (LOAD) randomized trial. Am Heart J. 2017;184:8896. https://doi.org/10.1016/j.ahj.2016.11.001.

113. Pineda A, Cubeddu LX. Statin rebound or withdrawal syndrome: does it exist? Curr Atheroscler Rep. 2011;13(1):23-30. https://doi.org/10.1007/ s11883-010-0148-X.

114. Le Manach Y, Godet G, Coriat P, Martinon C, Bertrand M, Fléron MH, et al. The impact of postoperative discontinuation or continuation of chronic statin therapy on cardiac outcome after major vascular surgery. Anesth Analg. 2007;104(6):1326-33.. table of contents.
115. Swärd K, Valsson F, Sellgren J, Ricksten SE. Differential effects of human atrial natriuretic peptide and furosemide on glomerular filtration rate and renal oxygen consumption in humans. Intensive Care Med. 2005;31(1):79-85.

116. Houben AJ, van der Zander K, de Leeuw PW. Vascular and renal actions of brain natriuretic peptide in man: physiology and pharmacology. Fundam Clin Pharmacol. 2005;19(4):411-9. https:// doi.org/10.1111/j.1472-8206.2005.00336.x.

117. Kuhn M. Endothelial actions of atrial and B-type natriuretic peptides. Br J Pharmacol. 2012;166(2):522-31. https://doi.org/10.1111/j.1476-5381.2012.01827.x.

118. Nigwekar SU, Navaneethan SD, Parikh CR, Hix JK. Atrial natriuretic peptide for preventing and treating acute kidney injury. Cochrane Database Syst Rev. 2009;4:CD006028. https://doi. org/10.1002/14651858.

119. Mitaka C, Kudo T, Haraguchi G, Tomita M. Cardiovascular and renal effects of carperitide and nesiritide in cardiovascular surgery patients: a systematic review and meta-analysis. Crit Care. 2011;15(5):R258. https://doi.org/10.1186/cc10519.

120. Xiong B, Wang C, Yao Y, Huang Y, Tan J, Cao Y, et al. The dose-dependent effect of nesiritide on renal function in patients with acute decompensated heart failure: a systematic review and meta-analysis of randomized controlled trials. PLoS One. 2015;10(6):e0131326. https://doi.org/10.1371/journal.pone.0131326.

121. Mori Y, Kamada T, Ochiai R. Reduction in the incidence of acute kidney injury after aortic arch surgery with low-dose atrial natriuretic peptide: a randomised controlled trial. Eur J Anaesthesiol. 2014;31(7):3817. https://doi.org/10.1097/EJA.0000000000000035.

122. Sezai A, Nakata K, Iida M, Yoshitake I, Wakui S, Hata $\mathrm{H}$, et al. Early results of human atrial natriuretic peptide infusion in non-dialysis patients with chronic kidney disease undergoing isolated coronary artery bypass grafting: the NU-HIT trial for CKD-II. Ann Thorac Cardiovasc Surg. 2014;20(3):217-22.

123. Sisillo E, Ceriani R, Bortone F, Juliano G, Salvi L, Veglia F, et al. N-acetylcysteine for prevention of acute renal failure in patients with chronic renal insufficiency undergoing cardiac surgery: a prospective, randomized, clinical trial. Crit Care Med. 2008;36(1):81-6. https://doi.org/10.1097/01. CCM.0000295305.22281.1D.

124. Wijeysundera DN, Beattie WS, Rao V, Granton JT, Chan CT. N-acetylcysteine for preventing acute kidney injury in cardiac surgery patients with preexisting moderate renal insufficiency. Can J Anaesth. 2007;54(11):872-81.

https://doi.org/10.1007/ BF03026790.

125. Macedo E, Abdulkader R, Castro I, Sobrinho AC, Yu L, Vieira JM Jr. Lack of protection of $\mathrm{N}$-acetylcysteine (NAC) in acute renal failure related to elective aortic aneurysm repair-a randomized controlled trial. Nephrol Dial Transplant. 2006;21(7):1863-9. https://doi.org/10.1093/ndt/ gfl079. 
126. Adabag AS, Ishani A, Koneswaran S, Johnson DJ, Kelly RF, Ward HB, et al. Utility of N-acetylcysteine to prevent acute kidney injury after cardiac surgery: a randomized controlled trial. Am Heart J. 2008;155(6):1143-9. https://doi.org/10.1016/j. ahj.2008.01.013.

127. Song JW, Shim JK, Soh S, Jang J, Kwak YL. Double-blinded, randomized controlled trial of $\mathrm{N}$-acetylcysteine for prevention of acute kidney injury in high risk patients undergoing off-pump coronary artery bypass. Nephrology. 2015;20(2):96102. https://doi.org/10.1111/nep.12361.

128. Fraga CM, Tomasi CD, Damasio DC, Vuolo F, Ritter C, Dal-Pizzol F. N-acetylcysteine plus deferoxamine for patients with prolonged hypotension does not decrease acute kidney injury incidence: a double blind, randomized, placebo-controlled trial. Crit Care. 2016;20(1):331. https://doi.org/10.1186/ s13054-016-1504-1.

129. Lynch RM, Robertson R. Anaphylactoid reactions to intravenous $\mathrm{N}$-acetylcysteine: a prospective case controlled study. Accid Emerg Nurs. 2004;12(1):10-5.

130. Sandilands EA, Bateman DN. Adverse reactions associated with acetylcysteine. Clin Toxicol. 2009;47(2):81-8. https://doi. org/10.1080/15563650802665587.

131. Cigarroa RG, Lange RA, Williams RH, Hillis LD. Dosing of contrast material to prevent contrast nephropathy in patients with renal disease. Am J Med. 1989;86(6 Pt 1):649-52.

132. Nyman U, Björk J, Aspelin P, Marenzi G. Contrast medium dose-to-GFR ratio: a measure of systemic exposure to predict contrast-induced nephropathy after percutaneous coronary intervention. Acta Radiol. 2008;49(6):658-67. https://doi. org/10.1080/02841850802050762.

133. Barrett BJ, Carlisle EJ. Metaanalysis of the relative nephrotoxicity of high- and low-osmolality iodin- ated contrast media. Radiology. 1993;188(1):171-8. https://doi.org/10.1148/radiology.188.1.8511292.

134. Lameire N, Kellum JA, KDIGO AKI Guideline Work Group. Contrast-induced acute kidney injury and renal support for acute kidney injury: a KDIGO summary (part 2). Crit Care. 2013;17(1):205. https:// doi.org/10.1186/cc11455.

135. Nijssen EC, Rennenberg RJ, Nelemans PJ, Essers BA, Janssen MM, Vermeeren MA, et al. Prophylactic hydration to protect renal function from intravascular iodinated contrast material in patients at high risk of contrast-induced nephropathy (AMACING): a prospective, randomised, phase 3, controlled, open-label, non-inferiority trial. Lancet. 2017;389(10076):131222. https://doi.org/10.1016/S0140-6736(17)30057-0.

136. Weisbord SD, Gallagher M, Jneid H, Garcia S, Cass A, Thwin SS, et al. Outcomes after angiography with sodium bicarbonate and acetylcysteine. N Engl J Med. 2018;378:603-14. https://doi.org/10.1056/ NEJMoa1710933.

137. Putzu A, Boscolo Berto M, Belletti A, Pasotti E, Cassina T, Moccetti T, et al. Prevention of contrastinduced acute kidney injury by furosemide with matched hydration in patients undergoing interventional procedures: a systematic review and metaanalysis of randomized trials. JACC Cardiovasc Interv. 2017;10(4):355-63. https://doi.org/10.1016/j. jcin.2016.11.006.

138. Subramaniam RM, Suarez-Cuervo C, Wilson RF, Turban S, Zhang A, Sherrod C, et al. Effectiveness of prevention strategies for contrast-induced nephropathy: a systematic review and meta-analysis. Ann Intern Med. 2016;164(6):406-16. https://doi. org/10.7326/M15-1456.

139. Anderson SM, Park ZH, Patel RV. Intravenous $\mathrm{N}$-acetylcysteine in the prevention of contrast media-induced nephropathy. Ann Pharmacother. 2011;45(1):101-7. https://doi.org/10.1345/aph.1P275. 